\title{
The Association Between Gratitude, Perceived Stress, and Burnout Among Firefighters in Jakarta
}

\author{
Monica Monica ${ }^{1}$ Niken Widi Astuti ${ }^{1 *}$ \\ ${ }^{1}$ Faculty of Psychology, Tarumanagara University, West Jakarta, Jakarta 11440, Indonesia \\ *Corresponding author. Email: nikenw@fpsi.untar.ac.id
}

\begin{abstract}
Perceived stress and burnout are often found in workers who have heavy jobs, one of which is a firefighter. Perceived stress and burnout could disrupt physical health. Firefighters should have good physical health because their work is quite tough, therefore to maintain physical health, firefighters could overcome the perceived stress and burnout through gratitude. This study aims to see the association between gratitude, perceived stress and burnout among firefighters in Jakarta. The subjects of this study were firefighters in East Jakarta. This research was conducted in August 2020. Participation in this study was conducted on 75 people. The method used in this research is a quantitative method using linear correlation techniques. The results of the study found that there was no relationship between gratitude, perceived stress and burnout in firefighters in East Jakarta.
\end{abstract}

Keywords: Gratitude, perceived stress, burnout

\section{INTRODUCTION}

Based on a report from the Dinas Penanggulangan Kebakaran dan Penyelamatan Provinsi DKI Jakarta (2019), fires that occur in Jakarta are generally caused by electricity, cigarettes, stoves, and others. The Dinas Penanggulangan Kebakaran dan Penyelamatan Provinsi DKI Jakarta (2019) also recorded fire cases that occurred from 2015 to 2019 in Jakarta. There were 1,692 fire cases that occurred in 2015, 1,047 in 2016, 2,055 in 2017, 1,528 in 2018, and 1,355 in 2019. Badan Penanggulangan Bencana Daerah (BPBD) DKI Jakarta in Clara [4] stated that, fires are the most frequent disasters in the capital city in 2019. Suku Dinas Penanggulangan Kebakaran dan Penyelamatan (Sudin PKP) in Kompas [11] also noted that, there were 579 fire cases occurred in East Jakarta throughout 2019 and when compared based on data from BPBD DKI Jakarta in 2018, East Jakarta has 177 fire cases, where the number of fire cases in East Jakarta more than tripled from the previous year.

Katsavouni et al. [10] suggest that firefighters work in physically and mentally demanding situations. They participate in activities along with intense physical stress, high temperatures and the harmful effects of inhaling toxic gases. Therefore, the health of firefighters really needs to be considered because it can affect their job performance. Apart from the influence of the work environment of firefighters that can endanger their physical health, firefighters often experience trauma which can affect their job performance. Firefighters are considered to have a tough

job, because physical hazards and psychological stress are part of their daily lives [1]. Harvey et al. [8] revealed that firefighters often experience trauma, and trauma plays an important role in emergency workers such as firefighters, researchers say that the more traumatic events that occur, the more likely the occurrence of Post-Traumatic Stress Disorder (PTSD) and depression. Puddey and Beilin [18] state that consuming alcohol can have a negative impact on blood pressure. This means that consuming alcohol has a negative impact on physical health. Disrupted physical health and trauma experienced by firefighters can result in the emergence of perceived stress and burnout.

Burnout is a psychological syndrome that is associated with a prolonged response to stress at work [1]. Burnout is a syndrome of emotional exhaustion, depersonalization, and decreased personal achievement that can occur among individuals who do 'people work' [13]. Burnout can also be interpreted as a long-term reaction to work stress [10], while perceived stress is a feeling or thought that a person has, the stress that is felt is not about measuring the frequency of stress events, but about how a person feels about general stress in their life and their ability to handle the stress [21]. The results of research conducted by Angelo [1] also show that burnout in firefighters increases as a consequence of working in the context of a rescue mission. Several studies have found that perceived stress was found to be higher among firefighters compared to other public works groups [9] According to Kristensen et al. [13], there were three dimensions to measure burnout. The three dimensions are: (a) personal burnout, (b) work-related burnout, and (c) client-related burnout. These dimensions appear based on the theory of Maslach and Jackson [15] According to Kristensen et al. [13], there are burnout factors, from non-work factors such as health problems or family demands, and psychosocial factors such as at work, 
family / work relationships, use of drugs, health and welfare, certain positions, sociodemographic factors, and lifestyle.

Perceived stress and burnout have also been shown to be significant predictors of PTSD disorders in firefighters [14]. Psychological stress occurs when individuals feel that environmental demands exceed that individual's adaptability. In general, stress events are thought to influence the pathogenesis of physical illness by causing negative affective states (for example, feelings of anxiety and depression), which have a direct effect on biological processes or behavioral patterns that affect disease risk [5]. Previous researchers also said that perceived stress mediated the relationship between traumatic stress and PTSD symptoms. This shows that exposure to traumatic events directly or indirectly arises through an individual's perceived stress which can affect the development of PTSD symptoms Lee et al [14]. From the previous research that has been done above, it shows that perceived stress and burnout can lead to other physical disorders. To overcome the emergence of physical disturbances in firefighters, perceived stress and burnout need to be addressed. Emmons and Crumpler in Krause [11] explain that gratitude can effectively help people to cope with the effects of stress. Perceived stress is based on the results of research using the Perceived Stress Scale (PSS) conducted by Cohen [5], with tax in its definition which is unidimensional or only one dimension. It was explained that this scale was designed to assess a person's perception of stress, their feelings and their understanding during the month of stress.

According to Sarafino and Smith [19] there are 3 components that cause stress, namely an environment in which stress is seen as a stimulus, such as when we have a demanding job or experience severe pain from inflammation to death in the family. Physically and psychologically challenging events or circumstances are called stressors. Stress can also arise from stress or strain, stress is seen as a response, focused on the individual's reaction to the stressor. Stress can be seen from transactions in which stress is seen as a process, and adds several important dimensions, namely the relationship between individuals and their environment [19]. This process involves continuous interaction and adjustment with people and the environment, each influencing and being influenced by the others.

Gratitude involves positive cognitive assessments and in a situation or event [14]. Gratitude is also defined as an emotional response to gifts and appreciation that is felt after someone becomes the beneficiary of altruistic actions [7]. A recent study shows that a positive effect is related to adaptation to stress in firefighters [14]. People who are grateful may feel a more intense gratitude for positive events, and may find it easier to live their daily lives [2]. Gratitude is based on personal perceptions as something inappropriate or unexpected is expressed in the form of gratitude or appreciation Chen et al [3]. Based on the explanation above, gratitude can be the way to overcome perceived stress and burnout. Individuals with high gratitude tend to experience lower stress [23]. McCullough et al. [16], revealed that there are 4 aspects of gratitude. The four aspects are: (a) intensity, (b) frequency, (c) span, and (d) density. McCullough et al. [16] explained that gratitude can arise from positive affective trait and well-being. Individuals who feel they have received help from others feel strengthened, trusted and valued, which can increase self-confidence and feel that they have social support for themselves, prosocial traits. Gratitude is recognized as a prosocial effect because it is a response to others that helps one's well-being, and spiritual traits. Grateful people are aware of other powers higher than humans that contribute to their general well-being.

Based on previous research conducted by Park et al [17], firefighters in Korea have high levels of work stress from physical and emotional work environments, and current officer's duties correlate significantly with suicidal ideation in the previous year, even after controlling for the effects of PTSD and depressive symptoms. Meanwhile in Jakarta, based on research conducted by Dewi and Utoyo [6] firefighters in Jakarta have a high level of psychological well-being.

\section{METHODS}

Characteristics of participants who will be used in this study are firefighters working in East Jakarta. The expected participants are those who participate when the fire occurs. The number of samples to be taken in this study was 75 peoples. The sampling technique used in this research is non-probability sampling with convenience sampling as a sample collection technique, based on Tabahnick and Fidell [21], the formula for calculating the minimum sample size is $50+8 \mathrm{~m}$. Then the minimum sample size in this study is 58 . The sample used in this study amounted to 75 people.

\subsection{Research Procedure}

Researchers distributed questionnaires to several fire stations in East Jakarta. Before distributing the questionnaire, researchers asked participants to fill out the questionnaire according to what they experienced and felt. Participants were also asked to fill out an informed consent before filling out a questionnaire to be given. After that they filled out a questionnaire given. After the questionnaire has been completed, the researcher collects the distributed questionnaire through google-form. After everything is collected, the researcher explains the purpose of the research. After that the researcher gave a reward as a form of gratitude for filling out the questionnaire.

After all the data has been collected, the researcher starts processing the data. Researchers processed the data using Linear Correlation techniques with the Statistical Package for the Social Sciences (SPSS) application version 25.

\subsection{Research Measurement}

In this study, the measuring instrument used to measure gratitude is the Gratitude Questionnaire-Six Item Form 
(GQ-6). This scale consists of 6 items based on four aspects of gratitude according to McCullough et al. [7], namely intensity, frequency, span, and density. This measuring tool is designed to assess individual differences in the tendency to experience gratitude in everyday life. Based on the results of the reliability test, the intensity dimension is only 1 item so it cannot perform the reliability test, the frequency dimension consists of 2 items $(\alpha=0.715)$ with a corrected item-total correlation value of 0.569 , the span dimension consists of 2 items $(\alpha=0.680)$ with a corrected item-total correlation value of 0.526 , and the density dimension only has 1 item so that it cannot perform a reliability test.

The measuring instrument used to measure perceived stress is The Perceived Stress Scale (PSS-10) designed by Cohen et al [5]. This scale is designed to measure the extent to which situations in an individual's life are rated as stressful. This scale consists of 10 items that are arranged based on individual experiences and perceptions of stress, their feelings and their understanding during the past month about stress. Based on the reliability test, the total items of perceived stress consisted of 10 items that had unidimensional dimensions $(\alpha=0.866)$ with a corrected item-total correlation value of 0.481-0.862.

The measuring instrument used to measure burnout is the Copenhagen Burnout Inventory (CBI) designed by Kristensen et al [13]. This measuring instrument is designed based on the theory of Maslach and Jackson [15]. This scale is designed to measure personal burnout, work-related burnout, and client-related burnout. This scale consists of 6 items on personal burnout, 7 items on work-related burnout, and 6 items on client-related burnout. In this study, the dimensions measured are personal burnout and workrelated burnout. Based on the results of the reliability test, the total items in the personal burnout dimension were 6 items $(\alpha=0.875)$ with a corrected item-total correlation value of 0.656-0.694. The work-related burnout dimensions consist of 7 items $(\alpha=0.922)$ with a corrected item-total correlation value of $0.698-0.853$

\section{FINDINGS AND DISCUSSIONS}

According to Table 1, the description of research participants based on data obtained by gender, shows that total male subjects were 73 participants with a percentage of $97.3 \%$ and female subjects were 2 participants with a percentage of $2.7 \%$.

Table 1 Description of research participants based on gender

\begin{tabular}{lll}
\hline Gender & Frequencies & Percentages \\
\hline Male & 73 & 97.3 \\
Female & 2 & 2.7 \\
\hline Total & 75 & 100 \\
\hline
\end{tabular}

Meanwhile, the data obtained by age in the Table 2 shows that respondents aged 20-30 years were 30 participants with a percentage of $51.5 \%$, respondents aged $31-40$ years were
37 participants with a percentage of $23 \%$, while respondents aged 41-50 years were 4 participants with percentage of $14 \%$ and respondents aged 51-60 years as many as 4 participants with a percentage of $11.6 \%$.

Table 2 Description of research participants based on age

\begin{tabular}{lll}
\hline Age & Frequencies & Percentages \\
\hline $20-30$ & 30 & 51.5 \\
$31-40$ & 37 & 23 \\
$41-50$ & 4 & 14 \\
$51-60$ & 4 & 11.6 \\
\hline Total & 75 & 100 \\
\hline
\end{tabular}

When viewed from the gratitude description of the firefighters, the processing results show the span dimension $(\mathrm{M}=12.89, \mathrm{SD}=1.311)$. Furthermore, the results show that the intensity dimension $(\mathrm{M}=6.71, \mathrm{SD}=0.950)$. Then on the dimension of density, the results show $(\mathrm{M}=6.55, \mathrm{SD}=$ 0.722 ). While on the frequency dimension, the results show $(\mathrm{M}=14, \mathrm{SD}=12.75)$. Meanwhile, the image of the perceived stress on the processing results of firefighters shows unidimensional dimensions $(\mathrm{M}=30.85, \mathrm{SD}=$ $5,853)$. The results of the burnout description of the fire fighting officers showed the personal burnout dimensions $(\mathrm{M}=22.39, \mathrm{SD}=3,869)$. Meanwhile, for work-related burnout, the results show $(\mathrm{M}=25.67, \mathrm{SD}=5.774)$.

Furthermore, according to Table 3, it is known that there are no variables that have a correlation with each other. It can be seen from the processed data, that gratitude does not have a significant correlation with perceived stress $(r=0.056, p$ $=0.634)$. Gratitude also did not have a significant correlation with burnout $(\mathrm{r}=.109, \mathrm{p}=0.351)$. The results also showed that perceived stress had no correlation with burnout $(r=-.099, p=0.400)$.

Table 3 Correlation test results

\begin{tabular}{|c|c|c|c|c|}
\hline & & Gratitude & $\begin{array}{l}\text { Perceived } \\
\text { Stress }\end{array}$ & Burnout \\
\hline Gratitude & $\begin{array}{l}\text { Correlation } \\
\text { Coefficient } \\
\text { Sig. (2- } \\
\text { tailed) }\end{array}$ & $\begin{array}{l}1.000 \\
.\end{array}$ & $\begin{array}{l}.056 \\
.634\end{array}$ & $\begin{array}{l}.109 \\
.351\end{array}$ \\
\hline $\begin{array}{l}\text { Perceive } \\
\text { d Stress }\end{array}$ & $\begin{array}{l}\text { Correlation } \\
\text { Coefficient } \\
\text { Sig. (2- } \\
\text { tailed) }\end{array}$ & $\begin{array}{l}.056 \\
.634\end{array}$ & $\begin{array}{c}1.000 \\
.\end{array}$ & $\begin{array}{l}-.099 \\
.400\end{array}$ \\
\hline Burnout & $\begin{array}{l}\text { Correlation } \\
\text { Coefficient } \\
\text { Sig. (2- } \\
\text { tailed) }\end{array}$ & $\begin{array}{l}.109 \\
.351\end{array}$ & $\begin{array}{l}- \\
.099 \\
.400\end{array}$ & $\begin{array}{l}1.000 \\
.\end{array}$ \\
\hline
\end{tabular}

According to Table 4 that based on the Kruskal-Wallis analysis to see differences in gratitude, perceived stress and burnout by age group, it was found that there was a significant difference in gratitude between age groups, $\mathrm{h}=$ $12.427, p=0.006$. Likewise with perceived stress, there was a significant difference between age groups $h=10.915, p=$ 0.012 . However, the burnout variable shows that there is no 
significant difference when viewed from the age group $\mathrm{h}=$ $3.441, \mathrm{p}=0.328$.

Table 4 Kruskal-Wallis test results

\begin{tabular}{|c|c|c|c|}
\hline & Gratitude & $\begin{array}{l}\text { Perceived } \\
\text { Stress }\end{array}$ & Burnout \\
\hline Kruskal-Wallis H & 12.427 & 10.915 & 3.441 \\
\hline Asymp Sig. & .006 & .012 & .328 \\
\hline
\end{tabular}

The results showed that the three variables in this study had no relationship, gratitude had no significant relationship with perceived stress, gratitude also did not have a significant relationship with burnout, as well as perceived stress which had no relationship with burnout. The results of the study which showed that there was no relationship could be caused by the lack of participants in this study. Several studies also indicate that there are personality factors that can influence the results of the study. Research conducted by Lee et al. [14] show that personality differences show different gratitude for each participant so that this can be one of the reasons for the absence of a relationship between gratitude, perceived stress, and burnout. Syahdianto et al. [20] suggest that the results of the study indicate that there is no relationship between stress and possibly caused by several factors, including organizational factors and work environment which are not measurable in the variable perceived stress in this study.

Another factor that affects the results of the study which shows that there is no relationship between the three variables is the presence of factors that are not measured in the measuring instrument used. According to McCullough et al [16], there are spiritual trait factors that can influence a person to feel grateful which is not measured in the GQ-6 measurement tool used in this study.

Based on data obtained from 75 participants, the largest number of participants were firefighters with the male gender, totaling 73 participants and aged 20-30 years. Based on place of birth, the majority of participants were born in Jakarta and work in the Cakung sector. The results of data collection show that in the gratitude variable, the span dimension is the biggest factor for firefighters to feel grateful, while in the burnout variable, work-related burnout is the biggest factor for firefighters to feel tired. Based on the gratitude description of participants based on age, there were 72 participants who felt grateful from 75 participants with the highest percentage in the dimensions of span, intensity, frequency, and density at the age of 3140 years. The picture of perceived stress in participants based on age shows that firefighters who often experience stress in the past month are firefighters aged 20-30 years with a total of 8 participants from 13 participants who experience stress, while the burnout picture in participants based on age shows that In both dimensions, namely personal burnout and work-related burnout, firefighters who often experience fatigue are firefighters aged 31-40 years.

The research that has been carried out has several limitations, including the difficult distribution of data during the COVID-19 pandemic, making it difficult for researchers to distribute questionnaires directly to the intended participants. Another limitation is the distribution of data using google form via the Whatsapp group which causes at least a few firefighters to fill out research questionnaires.

\section{CONCLUSIONS}

The conclusion from the results of this study is that there is no significant relationship between gratitude and perceived stress, there is no significant relationship between gratitude and burnout, and there is no significant relationship between perceived stress and burnout in firefighters in Jakarta.

The concepts of gratitude, perceived stress, and burnout are quite broad concepts, therefore, it is recommended that further researchers conduct more in-depth research on the factors and roles between gratitude, perceived stress, and burnout in firefighters in Jakarta. The personality of each firefighter also needs to be further investigated and to conduct a larger amount of research. It is also recommended to measure the personality factors for each firefighter.

A similar study was conducted by Syahdianto et al [20] which shows that there is no relationship between stress and fatigue in field workers in Indonesia. Research conducted by Chen \& Chang [3] found that there is no reciprocal relationship between gratitude and fatigue.

\section{ACKNOWLEDGMENT}

Researcher would like to thank the university for the opportunity, every participant who was willing to participate and everyone who has contributed to this research.

\section{REFERENCES}

[1] R. P. Ângelo, M. J. Chambel. The reciprocal relationship between work characteristics and employee burnout and engagement: A longitudinal study of firefighters. Stress and Health. 31 (2013) 106-114. https://doi.org/10.1002/smi.2532

[2] D. W. Chan. Gratitude intervention and subjective well-being among Chinese school teachers in Hong Kong. Educational Psychology. 30(2) (2010) 139-153. https://doi.org/10.1080/01443410903493934

[3] L. H. Chen, Y. P. Chang. Cross-Lagged Associations between Gratitude and Adolescent Athlete Burnout. Current Psychology. 33(4) (2014) 460-478. https:// doi.org/10.1007/s12144-014-9223-8 
[4] M. T. Clara, D. H. BPBD DKI: Kebakaran mendominasi bencana di Jakarta pada 2019. Tempo. 2019. https://metro.tempo.co/read/1190173/bpbd-dkikebakaran-mendominasi-bencana-di-jakarta-pada-2019

[5] S. K. T. Cohen, \& R. A. Mermelstein. Global measure of perceived stress. Journal of Health and Social Behavior. 24(4) (1983) 385. https://doi.org/10.2307/ $\underline{2136404}$

[6] H. C. Dewi, \& S. D. B. Utoyo. Psychological wellbeing pada petugas pemadam kebakaran di Jakarta. Universitas Indonesia. 2013. http://www.lib.ui.ac.id/ naskahringkas/2015-09/S-Hellen\%20Citra\%20Dewi

[7] R. A. Emmons, \& C. A. Crumpler. Gratitude as a human strength: Appraising the evidence. Journal of Social and Clinical Psychology. 19(1) (2000) 56-69. https://doi.org/10.1521/jscp.2000.19.1.56

[8] S. B. Harvey, J. S. Milligan-Saville, H. M. Paterson, E. L. Harkness, A. M. Marsh, M. Dobson, R. Kemp, \& R. A. Bryant. The mental health of fire-fighters: An examination of the impact of repeated trauma exposure. Australian and New Zealand Journal of Psychiatry. 50 (2016) 649-658. $\quad$ https://doi.org/10.1177/ $\underline{0004867415615217}$

[9] W. Jang, D. Kim, H. Park, \& J. Kim. Mental health and quality of life in firefighters working on the scene in South Korea: Focused on the capital area and the ground pro-motion area. Brain and Behavior. 2020. https:// doi.org/10.1002/brb3.1559

[10] F. Katsavouni, E. Bebetsos, P. Malliou, \& A. Beneka. The relationship between burnout. PTSD symptoms and injuries in firefighters. Occupational Medicine (London). 66 (2016) 32-37. https://doi.org/ $10.1093 / \mathrm{occmed} / \mathrm{kqv} 144$

[11] Kompas Cyber Media. 579 Kasus Kebakaran Terjadi Di Jakarta Timur Sepanjang 2019. Cakung paling sering. KOMPAS. 2019. https://megapolitan. kompas.com/read/2019/12/31/18340451/579-kasuskebakaran-terjadi-di-jakarta-timur-sepanjang-2019cakung-paling

[12] N. Krause. Gratitude toward god, stress, and health in late life. Research on Aging. 28(2) (2006) 163-183. https://doi.org/10.1177/0164027505284048

[13] T. S. Kristensen, M. Borritz, E. Villadsen, \& K. B. Christensen. The Copenhagen Burnout Inventory: A new tool for the assessment of burnout. Work \& Stress. 19(3) (2005) 192- 207. $\quad$ https://doi.org/10.1080/ $\underline{02678370500297720}$
[14] J. Y. Kim, S. Y. Bae, K. Y. Kim, J. M. Shin, I. S. Yoon, J. S, \& S. W. Kim. The association of gratitude with perceived stress and burnout among male firefighters in Korea. Personality and Individual Differences. 123 (2018) 205-208. https://doi.org/10. 1016/j.paid.2017.11.010

[15] C. Maslach, \& S. E. Jackson. The measurement of experienced burnout. Journal of Organizational Behavior. 2(2) (1981) 99-113. https://doi.org/10.1002/ job.4030020205

[16] M. E. McCullough, R. A. Emmons, \& J. A. Tsang. The grateful disposition: A conceptual and empirical topography. Journal of Personality and Social Psychology. 82(1) (2002) 112-127. https://doi.org/ $\underline{10.1037 / 0022-3514.82 .1 .112}$

[17] H. Park, J. I. Kim, B. Min, S. Oh, \& J. H. Kim. Prevalence and correlates of suicidal ideation in Korean firefighters: a nationwide study. BMC Psychiatry. 19(1) (2019). https://doi.org/10.1186/s12888-019-2388-9

[18] I. B. Puddey, \& L. J. Beilin. Alcohol is bad for blood pressure. Clinical and Experimental Pharmacology and Physiology. 33(9) (2006) 847-852. https://doi.org/10. $\underline{1111 / \mathrm{j} .1440-1681.2006 .04452 . \mathrm{x}}$

[19] E. P. Sarafino, \& T. W. Smith. Health psychology: Biopsychosocial interactions (7th ed.). Hoboken. N.J.: John Wiley \& Sons. 2012.

[20] Syahdianto, J. M. L. Umboh, P. A. T. Kawatu, \& N. S. H. Malonda. Hubungan antara stres kerja dengan tingkat kelelahan kerja pada pekerja lapangan bagian produksi PT. J Resources Bolaang Mondongow. Universitas Sam Ratulangi Manado. 1-9 (2012) https://fkm.unsrat.ac.id/wp-content/uploads/2012/10/ Syahdianto.pdf

[21] B. G. Tabachnick, \& L. S. Fidell. Using multivariate statistics (new international ed.). Harlow: Pearson. 2014.

[22] R. P. Varghese, T. S. J. Norman, \& S. Thavaraj. Perceived stress and self-efficacy among college students: A global review. SSRN. 5(3) (2015) 15-24. http://dx.doi.org/10.2139/ssrn.2703908

[23] M. Yildirim, \& Z. Alanazi. Gratitude and Life Satisfaction: Mediating Role of Perceived Stress. International Journal of Psychological Studies. 10(3) (2018) 21. https://sci-hub.se/10.5539/ijps.v10n3p21 